DOI: $10.22363 / 2312-9182-2019-23-1-23-39$

\title{
Creativity in Metaphor Interpretation
}

\author{
Andreas Musolff \\ School of Politics, Philosophy, Language and Communication Studies \\ University of East Anglia \\ Norwich Research Park, Norwich NR4 7TJ, UK
}

\begin{abstract}
This paper looks at corpus- and survey-based evidence of innovative interpretative metaphor use that changes the default meaning of well-established figurative constructions. Specifically, we look at interpretationinduced changes in the meaning of corporeal metaphors, on the basis of a corpus of British political discourse and a questionnaire survey of more than 1000 respondents from 31 linguistic backgrounds in 10 countries. The corpus-based evidence consists of metaphor-production data that show how situational variation in metaphor use can over time create a semantic-pragmatic drift that changes the dominant meaning of a conventional metaphor expression. The questionnaire survey reveals four distinct models for BODYfocused readings (i.e. NATION AS GEOBODY, AS HIERARCHICAL FUNCTIONAL WHOLE, AS PART OF SPEAKER'S BODY, AS PART OF LARGER BODY), plus a further set PERSON-focused readings. The two most frequent BODY-focused interpretations, i.e. NATION AS GEOBODY and NATION AS HIERARCHICAL FUNCTIONAL WHOLE, as well as the PERSON-stereotypes versions show divergent frequency and elaboration patterns across the Chinese- vs. English-L1 respondent groups, which may be linked to specific cultural conceptual and discursive traditions. Both data sets indicate a strong creative element in metaphor interpretation, which accounts for a significant degree of variation in the creation of new metaphorical concepts.
\end{abstract}

Keywords: Creativity, corpus, discourse history, interpretation, metaphor reception, NATION AS BODY/ PERSON, questionnaire survey, variation

\section{Творческая интерпретация метафор}

\author{
Андреас Музолф \\ Факультет политики, философии, лингвистики и теории коммуникации, \\ Университет Восточной Англии \\ Norwich Research Park, NR4 7TJ, Норвич, Великобритания
}

В статье рассматривается инновационное творческое осмысление метафор, меняющее значение устойчивых образных выражений. В частности анализируются интерпретационные изменения в семантике телесных метафор. В качестве материала выступают корпус британского политического дискурса и результаты опроса более 1000 респондентов из 10 стран, говорящих на 31 языке. Корпусные данные показывают, каким образом ситуативные вариации в использовании метафор могут со временем формировать семантико-прагматические тенденции, меняющие доминантное значение устойчивых метафорических выражений. Опрос позволяет выделить четыре модели прочтения ТеЛеСНЫХ МеТафОр (НАЦИЯ КАК ГЕОСТРУКТУРА, ИЕРАРХИЧЕСКИ ФУНКЦИОНИРУЮЩЕЕ ЦЕЛОЕ, ЧАСТЬ ТЕЛА ГОВОРЯЩЕГО, ЧАСТЬ БОЛЕЕ КРУПНОГО ЦЕЛОГО), а также их последУющие антропоцентричные осмысления. Две наиболее распространенные интерпретациИ - НАЦИЯ КАК ГЕОСТРУКТУРА и ИЕРАРХИЧЕСКИ ФУНКЦИОНИРУЮЩЕЕ ЦЕЛОЕ, а также варианты стереотипизации личности, демонстрируют несов- 
падение частотности и толкования соответствующих единиц респондентами - носителями китайского и английского языков, что может быть связано с культурно-специфическими концептуальными и дискурсивными традициями. Оба вида данных указывают на наличие мощной творческой составляющей в интерпретации метафор, что объясняет вариативность при создании новых метафорических понятий.

Ключевые слова: креативность, корпус, история дискурса, интерпретация, восприятие метафор, НАЦИЯ КАК ТЕЛО/ЧЕЛОВЕК, опрос, вариативность

\section{INTRODUCTION}

When and where is a metaphor created: in the production event when a speaker utters it, or in the reception event when it is interpreted by one (or several) recipient(s)? Is the speaker's intended meaning the only meaning that matters for the receiver in terms of the utterance's figurative status, (target-)reference and contextually relevant connotations? Does the receiver's interpretation of the metaphor count as a mis- or nonunderstanding if it does not match exactly the speaker's intended meaning? Or can it constitute a new figurative meaning, which may even be endorsed by the speaker subsequently? If yes, do we not need to view a metaphor's meaning as variable or flexible, perhaps even in its production, i.e. in the sense of the speaker allowing for varying interpretations?

Two main types of answers have been proposed to tackle such questions. One type consists of more or less nuanced differentiations between "novel"/"creative", "conventional", "dead" and "sleeping" metaphors, the latter with various degrees of "revivability" (Goatly 1997; Lakoff 1987; Müller 2008). Novel metaphors are then treated as a special sub group of figurative expressions that require a "deliberate" cognitive and communicative effort on the part of the speaker and a corresponding interpretative effort on the part of the hearer/reader (Weinreich 1983; Steen 2008, 2011; Sperber \& Wilson 1995, pp. 235-237; Tendahl \& Gibbs 2008), which can entail a complex "conceptual integration" process (Fauconnier \& Turner 2002) and further pragmatic exploitation by way of irony and sarcasm (Musolff 2017a). Conventional and fully lexicalized metaphors, on the other hand, are deemed to be produced and understood "automatically" (Lakoff 1993, 2008) and as having reached (or nearly reached) the end of their "career" or "evolution" as figurative meanings (Bowdle \& Gentner 2005; Croft \& Cruse 2004, pp. 204-206).

A second main avenue to deal with production-reception aspects of metaphor creation has been to allow for semantic variation of metaphors in both production and reception as a context- and culture-specific phenomenon (Barnden 2009; Kövecses 2005, 2006, 2009; Idström \& Piirainen 2012; Musolff, MacArthur \& Pagani 2014), with various degrees of reach in terms of the linguistic levels affected: discourse, lexical and grammatical systems. Recent research on foreign Language Acquisition, Language Contact and Lingua Franca has provided ample evidence that 'creative misunderstanding' of metaphors by learners and can be used as a pedagogic tool rather than as an "error" phenomenon that has to be eradicated (Littlemore 2001, 2003; Littlemore et al. 2011; Nacey 2013; Philip 2010; Piquer-Píriz 2010; Trim 2012).

This paper explores innovative metaphor use in both production and interpretation with a combination of two methods, i.e. corpus- and survey-analysis. Specifically, we 
look at interpretation-induced changes in the meaning of the CENTRE-AS-HEART and NATION-AS-BODY metaphors ${ }^{1}$, using data from a) a corpus of British figurative discourse on European politics; and b) a questionnaire survey of more than 1000 students from 31 linguistic backgrounds. Both data sets indicate a strong production element in elicited metaphor (re-)interpretation, which goes beyond mere semantic extension of conventional metaphors. Rather, the production element in metaphor (re-)interpretation accounts for considerable variation and, in some cases, creation of new metaphorical concepts. After surveying and analysing the evidence from both data sets, we will discuss their significance for a model of the relationship of production and reception sides in figurative language use $\mathrm{e}^{2}$.

\section{CREATIVE RECYCLING OF A METAPHORICAL SLOGAN: BRITAIN AT THE HEART OF EUROPE}

The public debate surrounding the referendum on the United Kingdom's exit ("Brexit") from the European Union (EU) has seen the revival of a metaphorical slogan that has been declared 'dead' several times already, i.e. that Britain is or should (not) be at the heart of Europe. Public voices opposing a "hard Brexit" have used it to suggest that the "UK has an 'ardent wish' to remain at [the] heart of Europe" (The Independent, 27/06/2017, reporting on a speech by the Chancellor of the Exchequer, Philip Hammond), whereas enthusiastic pro-Brexit voices, such as the Daily Telegraph's editor J. Warner, have employed the metaphor to paint the picture of "the heart of the European project" being full of "deep contempt $<$... > for the collective will and concerns of the people", when responding to qualified criticisms of the British referendum by the EU leaders Juncker and Van Rompuy (The Daily Telegraph, 23/08/2016).

These examples are just two instances of 248 texts documenting the discoursehistorical development of the slogan Britain at the heart of Europe as part of a bilingual English-German "EUROMETA" corpus of figurative press texts on EU-politics, which goes back to 1989 and reaches until September 2017. Overall, the corpus is 612.000 words large and has more than 2500 separate text entries (Musolff 2004a). The British sample alone is over 390.000 words large, with the HEART-BODY-HEALTH source domain alone accounting for texts amounting to 113.191 words, drawn from a broad spectrum of newspapers and magazines (print and online versions) ${ }^{3}$. The heart of Europe sub-sample yields 9-10 texts per year on average, with peak occurrences $(>20)$ in 1991, 1995, 1999 and 2016. As the search did not cover all newspapers for all years, our data can only be interpreted as representing the range of types of uses, not their overall or (statistically) relative frequencies. These are in any case difficult to calculate, as almost two thirds (i.e., $73 \%,=181$ out of 248 texts) quote or allude to the slogan as used by other speakers

${ }^{1}$ SMALL CAPITALS here and further in the text indicate conceptual categories (source and target domains, single concepts); italics indicate types of formulations (or titles of newspapers, books etc.).

2 This paper also includes materials presented in previous research of the author on this subject (Musolff 2016, 2017a,b).

3 Specifically, Daily Express, Daily Mail, Eastern Daily Press, Financial Times, New Statesman (previously: New Statesman \& Society), The Daily Telegraph, The Economist, The Guardian/Observer, The Independent, The Northern Echo, The Scotsman, The Spectator, The Sun, The Sunday Times, The Times. 
or as being publicly known. Hence, even a total count of all press and other media occurrences of the heart of Europe slogan, if feasible, would largely consist of secondary instances of more or less prominent quotations rather than original uses. Our sub-sample of heart of Europe uses in EUROMETA, however, allows a good overview over the conceptual variation and pragmatic exploitation of the slogan as well as of its 'discursive drift' from an optimistic policy-promise towards its ("euro"-)sceptic denunciation as a pointless, doomed project (Musolff 2004b, 2013).

The notion of 'discursive drift' is introduced here as a counterpart to "semantic drift" (Croft \& Cruse 2004, p. 205), to capture changes in the stances taken by users of conceptual metaphors that become visible over shorter or longer time frames. Some conceptual metaphors can be traced back over hundreds and thousands of years, such as the LOVE-WAR and ILLNESS-WAR analogies (Sontag 1978; Trim 2011), the ontological-theological CHAIN-OF-BEING concept (Kövecses 2002, pp. 124-126; Lakoff \& Turner 1989, pp. 166-172; Lovejoy 1936), or the politico-sociological NATION-ASBODY/PERSON metaphor, which was lexicalised in English as the term body politic (Charbonnel 2010; Chilton \& Lakoff 1995; de Baecque 1997; Guldin 2000; Kantorowicz 1997; Musolff 2010). Shorter discourse histories can be observed over several years or decades; the HEART OF EUROPE concept, which has featured in British debates about the UK's position vis-à-vis the European Union, falls into this latter category.

The slogan, Britain at the heart of Europe, was launched by the former Conservative Prime Minister, John Major, in a speech in Bonn, Germany, in March 1991. Major promised, "Our government will work at the very heart of Europe with its partners in forging an integrated European community" (The Guardian, 12/03/1991). Here, the phrase, at the heart, was employed by the speaker (and interpreted by the media) in the conventional, only weakly metaphorical sense of 'heart-as-centre' (Shorter Oxford English Dictionary 2002, vol. 1, p. 1213 and Roget's International Thesaurus, 1996, p. 143). In combination with the qualifier "of Europe" (metonymy for "European Community" (EC), as the "European Union" was then still called), the phrase designated a policy promise that would entail a break with the more distanced stance towards the EC taken by his predecessor, Margaret Thatcher. The magazine, The Economist, took the new policy for granted: "Of course Britain should be at the heart of Europe whenever it possibly can, for that is where the decisions that affect many British interests are being taken" (The Economist, 23/11/1991). This reading was endorsed by Major himself in his autobiography which appeared nearly a decade later (Major 2000, pp. 268 - 269). The Tory-critical Guardian assessed the slogan as an astute political formulation, because it left "supporters and critics of Euro-federalism claiming [that Major] had signalled a decisive shift in their direction" (The Guardian, 13/03/1991).

Towards the end of 1991, however, after negotiations for a new EU Treaty had led to his government's “opt-out" from the planned common EU-currency, Major's parliamentary opponents questioned his closeness to Europe's heart by contrasting his speech with the negotiation results. The Labour Party leader, N. Kinnock, asked him how he could "claim to be at the heart of Europe when, because of his actions, our country is not even part of the key decisions [about future EC policies]" (Hansard 
11/12/1991), and the leader of the Liberal Democrats, P. Ashdown, alleged that Major had in fact "condemned" the UK "to be semi-detached from [the heart of Europe]" (ibid.). The slogan's metarepresented meaning in such criticisms clearly hinged on the HEART-AS-CENTRE interpretation.

During the following years, Major's statement was quoted time and again as a point of reference for his officially positive stance on Europe, with most commentators tacitly assuming that being close to the EU's HEART-AS-CENTRE was both desirable and feasible. But this view changed when, in August 1994, the French and German government parties published proposals for further political EU integration. They envisaged a division of the Union into an "inner core" or "circle" of member states committed to faster socio-economic integration, and several "outer circles" of less committed states, to which Britain belonged. Without negating or contradicting Major's slogan explicitly, the exclusion of Britain from the EU's "inner core" effectively undermined any pretence of it being at or close to Europe's heart. Major rejected the proposals within days, and the Independent newspaper pointed out his dilemma of being too close to the centre of EU policy for his increasingly Eurosceptic party's liking and not sufficiently close enough in the eyes of France and Germany with a pun on the idiom 'out on a limb' (Brewer's Dictionary of Phrase \& Fable 1999, p. 864): "He wanted Britain to be at the heart of Europe. Yet too often he found himself alone at the end of a limb" (The Independent, 08/09/1994).

Shortly afterwards, the Independent published an even more drastic verdict: "One British metaphor, at least, has ceased to beat. John Major said in Bonn in March 1991, that he wanted to put Britain 'where we belong, at the very heart of Europe'. $<\ldots .>$ if Mr Major wanted to be at the heart of Europe, it was, presumably, as a blood clot" (The Independent, 11/09/1994). By re-contextualising the quoted slogan through referencing a heart attack (ceased to beat, blood clot), the writer resuscitated the corporeal aspects of the HEART source concept in such a way as to present both the object-level referent - the centre of Europe - and the heart-metaphor as dying entities. This elaborate blend (Fauconnier \& Turner 2002, pp. 126-131) of at least one source and several target conceptual inputs yields extra communicative and cognitive effects of irony and evaluation, which also make extra comprehension efforts by the reader worthwhile.

The Independent was not the first media publication to attempt such a revitalization of the 'organic' aspect of the HEART-AS-ORGAN metaphor by linking it to ILLNESS-concepts: two years earlier, after the Pound Sterling had been forced by speculators to leave the "European Exchange Rate Mechanism", the Economist had already seen a "Coronary in Europe's new heart" (26/09/1992). However, after 1994, this pattern of revitalizing the metaphor by denouncing its connotational source content (HEALTHY HEART) became more and more attractive to the critics of Major's policy: thus, the Guardian (09/02/1995) called the Prime Minister's heart of Europe-ambition "less than full-blooded", and a former EU official B. Connolly published a book alleging corruption and incompetence in the EU administration under the title The Rotten heart of Europe (Connolly 1995), which was advertised across the whole British press and, predictably, became a favourite with EU-sceptics. Further ILLNESS-referencing uses of the metaphor followed, e.g. that Major was "blocking [Europe'] arteries" (former Prime Minister E. Heath, quoted 
in The Daily Telegraph, 21/06/1996), or the explicit conclusion that "if the heart of Europe [was] diseased, there [was] no point at being at the heart of Europe" (former Chancellor N. Lamont, quoted in The Guardian, 10/10/1996).

After winning the UK election of 1997, the Labour government under Tony Blair was keen to claim Britain at the heart of Europe as an optimistic slogan for themselves (The Guardian, 10/06/1997); however, even within his first year the Guardian highlighted its quick loss of meaningfulness: "The litany passes from government to government. A Britain at the heart of Europe. We'll hear the chant 1,000 times again this month $\langle\ldots>$. But hold the stethoscope and listen carefully, for the heart has some curious murmurs. $<\ldots>$ [The issues actually discussed by the officialdom of Brussels] bear no relationship to the British "debate", hearts, livers, gall bladders and all" (The Guardian, 01/12/1997). In this example, the dismissive qualification on the slogan as a "litany" or "chant" was escalated, as it were, by a further exploitation of the medical domain (stethoscope, heart's murmurs), that led up to the contemptuous punch-line of connecting the "heart" debate with a list of 'lower' body-organs, "livers, gall bladders and all".

Denunciations of the heart of Europe became again highly popular at further crisismoments in the EU-UK relationship, e.g. in the 1999 nepotism scandal, which inspired large sections of the British press to compete for the most damning evaluations: "the rotten heart of Europe will never be cleaned out" (The Sun, 17/03/1999); "[markets fear] a political vacuum at the heart of Europe" (The Guardian, 17/03/1999), "changes in personnel will not be enough to stop the rot at the heart of the EU" (Daily Mail, 17/03/1999); "abruptly the heart of Europe got sick" (The Economist, 18/03/1999); "a hole suddenly opened up at the heart of the European Union" (The Independent, 21/03/1999). In the 2000s, during every disagreement between the UK and the whole or parts of the EU on issues such as financial policy or immigration and free-movement policies, the heart-of Europe promise kept being denounced by contrasting it with allegedly more relevant, but derogatory body references, e.g. "Tony Blair says he wants Britain to be at the heart of Europe. Well it looks this morning as if Europe is showing us its backside" (The Sun, 03/09/2001), or hints at flaws that impeded its proper functioning: a "definitive split at the heart of Europe. (The Guardian, 16/12/2003); "the timebomb at the heart of Europe" (The Economist, 15/11/2012); or a Cracked heart (with Germany, rather than Britain, "sit[ting] uneasily at the heart of Europe" (New Statesman, $14 / 03 / 2013)$.

From autumn 2014 onwards the public debate about a referendum on Britain's EU-membership under the conservative Prime Minister David Cameron became the main thematic context of the slogan's use. Once again, denouncing the heart of Europe became a popular pastime among euro-sceptic politicians and journalists, despite a few 'rearguard' optimistic uses by pro-heart of Europe politicians such as Major and Blair, whose historic promises were still remembered - but mainly as having become obsolete (Daily Express 11/03/2016, Northern Echo, 09/06/2016, The Independent, 22/06/2016). After the referendum was eventually held in 2016 and yielded a pro-withdrawal result, the heart of Europe was once more viewed as dead, on account of Britain having "plunged a dagger" into it (The Independent, 26/06/2016). Nevertheless, it has reappeared in the discourse of Brexit-detractors such as the Scottish Independence campaigners 
who want Scotland (without the rest of the UK) to be at the heart of Europe (The Independent, 15/12/2016; Daily Express, 18/12/2016). As the introductory examples have shown ('ardent wish to remain at the heart of Europe' — with the heart as a desirable place vs. 'contempt for the will of the (British) people will at the heart of Europe' with the heart as a kind of national enemy) continues to provide a reference point for pro- and contra-Brexit commentators even in 2017.

Reviewing the slogan's development, we can characterise its central metaphor as a focus of public debate that has been 'kept alive' by repeated reformulations, allusions, and meta-communicative comments and in the process changed its evaluative connotations. Its initial uses and interpretations in 1991 were still based on the conventional HEART-AS-CENTRE meaning, which is fully lexicalised and could be even considered a "dead" or "sleeping" figure of speech. Innovative usage of the metaphorical slogan can be discerned in the sarcastic reinterpretations that revived its latent organismic/corporeal source domain, i.e. that of THE HEART AS A BODY ORGAN THAT CAN FALL ILL AND DIE. It was this specific metaphor "scenario" (Musolff 2006) of the unhealthy condition of the EU heart or arteries (e.g., blocked, cracked, dead, dirty/smelly, hollowed-out, rotten, sick/ill/diseased, and characterizations such as blood clot, flaw, hole, split, time bomb, vacuum at the heart, heart crisis, heart of stone, no heart, time-bomb at the heart, threatened by euro-sclerosis), together with the juxtaposition of the heart with 'low' or 'embarrassing' body parts (backside, gall bladder, liver) used by EUsceptics that challenged and changed the neutral-positive default assumption of the heart-position being important and desirable (because of its centrality).

If the heart as the organ of a figurative body politic is ill, dysfunctional or irrelevant, the desirability of being at or close to it is diminished, if not destroyed. As a further pragmatic effect, we can identify a denunciation effect that functions as "implicational impoliteness" (Culpeper 2011: 165-167) against a specific politician's or group of politicians' public face. By attacking their quoted (or alluded to) promise of a Britain at the heart of Europe, the targeted speakers were supposedly revealed as and accused of being incompetent, hypocritical, or even dangerous. These ironical and/or sarcastic uses still presuppose the optimistic usage, if only as the foil against which they must be understood; so in a sense, the optimistic promise version of the slogan has never disappeared completely from the conceptual "scenario" that is evoked by the metaphor. The media in fact reminded their audience from time to time which politician or party allegedly 'owned' the slogan in its optimistic version, but the communicative context was almost always a confrontational one: Politician X (e.g. Major or Blair) was depicted as having announced or promised or believed 'that Britain is/should be at the heart of Europe', only to be criticised for not fulfilling the promise or being ignorant of a changed (health) condition of the heart etc., which is more or less drastically exposed by the commentator. This 'discursive drift' of the slogan can be discerned in the decline (though not disappearance) of the non-quotative, assertive uses of the optimistic version over the course of 25 years, whilst critical quotations and denunciations of the presupposed optimistic Britain at the heart of Europe promise gained in prominence, especially in the run-up to and the aftermath of the 2016 Brexit referendum. 
In retrospective, it might even be argued that it was precisely the slogan's denunciations by way of the organismically and pejoratively reinterpreted HEART metaphor that prevented it from being forgotten. The promise to put $X$ at the heart=centre of $Y$ only lent itself to relatively weak endorsements or criticisms (as the initial reactions to Major's and Blair's uses showed), whereas the introduction of gory physical or medical details about the heart and arteries of the EU as being blocked, dying, rotting etc. ensured the slogan's continued presence in the public debate.

As the result of surveying this first set of examples, we can identify a strong productive element in the (critical) re-interpretations of the metaphorical slogan of Britain at the heart of Europe insofar as they changed the relevant source domain (from CENTRALITY to BODY-HEALTH), as well as the evaluative connotations and default stance from DESIRABLE to UNDESIRABLE and provided a platform for further pragmatic effects (irony and sarcasm). Together, these discourse-historical developments have changed the slogan's dominant reception into that of an "echoic", "metarepresented" utterance (Sperber 2000; Wilson \& Sperber 1992: 57-66; 2012, pp. 128-134) that is mainly remembered as a 'once famous' metaphor and thus has, arguably, for many members of the British public a historical association.

Perhaps two main lessons can be learnt from this part of the evidence under consideration:

a) Whilst the referential target of a metaphorical formulation may stay, roughly speaking, the same, i.e. in our case, the centre (of EU politics or political decision taking) as the heart of Europe, its connotations and stance-taking framing power can be 'turned around' or reversed, due to discursive developments that are beyond the control of the initial speaker(s). The changes in the UK's public's dominant attitudes toward the EU were in fact resisted and opposed by the two most prominent 'proposers' of the slogan, Major and Blair; still their own metaphor was quoted, interpreted and reinvented against them repeatedly until it meant the opposite of what they intended: instead of expressing an optimistic promise, it was used to draw the conclusion that there was no point in being close or engaging with a heart that was diseased, dead, or empty. The reinterpretation was not wrong or absurd - after all, it still referred to the same referent and gave an argument by analogy to outline the cognitive frame - but if a metaphor's conceptual and ideological force is at all to be taken seriously on the basis of Conceptual Metaphor Theory (CMT), as pioneered in the writings by George Lakoff and his disciples ${ }^{4}$, then its ideological reversal has to be acknowledged.

b) Such conceptual reversal (and any other variation) of metaphor production takes place in new pragmatic contexts of usage, such as rhetorical competition for innovative formulations and polemical confrontation that are characteristic for political discourse. However, this is by no means a 'creatio ex nihilo' but,

${ }^{4}$ See Chilton \& Lakoff 1995; Fauconnier \& Turner 2002; Kövecses 2002, 2005, 2006, 2009; Lakoff 1987, 1993, 1996, 2003, 2004, 2008, 2013; Lakoff \& Johnson 1980/2003 and 1999; Lakoff \& Turner 1989 . 
on the contrary, includes and often explicitly highlights the 'deliberate' (Steen 2011) creative reinterpretation of preceding metaphor uses, in order to underline the proposed conceptual-ideological change. Production and reception/understanding of a metaphor should therefore not be seen as the opposite ends of a linear, one-way process but rather as complementary aspects of a dialogical, if not 'multi'or 'pluri-logical' meaning negotiation, which needs to be viewed in its situational and discourse-historical context to be fully evaluated. The following section aims at providing further evidence for this perspective on metaphor production and reception by looking at elicited responses to a metaphor interpretation task.

\section{PRODUCTIVE INTERPRETATION: ELICITED CREATION OF NEW METAPHORS IN QUESTIONNAIRE RESPONSES}

When teaching a course on figurative language for British and international MA students at the University of East Anglia (UK) in 2011, I ran a brief class test to make sure that the recently mentioned phrase body politic had been correctly understood by the students. $50 \%$ of them were Chinese, the other half was made up of British, USAmerican, European, Kurdish and Arab students. The test instruction asked them to explain the meaning of body politic with reference to their home nations. Here are a few examples of student responses:

- The head of the body represents the Queen of England, as she is in charge of the whole country and she is royalty. The features of the head (eyes, nose, mouth and ears) represent the different official people, such as politicians, the Prime Minister, the Government.

- The nation is like the human body, if one part of the body suffers, the whole body suffers from fever $<\ldots>$.

- Beijing: Heart and Brain, Shanghai: Face (economic center); Hong Kong and Taiwan: Feet; Tianjin: Hands (= army close to Beijing); Shenzhen: Eyes (= the first place open to the world).

- Beijing: brain (control country) < ..> . Hong Kong: face (familiar to everyone); Taiwan: hair (we can live without hair [but to] have hair is more beautiful fashion.

It will come as no surprise that the first two examples were produced by a British and US student respectively and the latter two by Chinese ones; what was unexpected was a perfect 50/50 split in the metaphor structuring between Chinese and non-Chinese responses. Non-Chinese students depicted the nation (state) through functionally and hierarchically motivated analogies between political and socio-economic institutions to the whole and parts of a human body, which reproduced parts of Western conceptual and discursive traditions dating from the Middle Ages and the Renaissance and lexicalised in the phrase body politic (see above). On the other hand, all of the Chinese students' responses were based on a mapping GEOGRAPHICAL SHAPE OF NATION ANATOMY OF A HUMAN BODY, salient parts of which were selected according to PLACEFOR-SOCIO-POLITICAL INSTITUTION/STATUS metonymies (e.g. BEIJING - SEAT OF GOV- 
ERnMent; Shanghai, Shenzen, Hong Kong — InTERnationally RELEVANT ECONOMIC CENTRES; TAIWAN — POLITICALLY SEPARATE ISLAND STATE; TIBET — PROVINCE WITH OUTLAWED INDEPENDENCE MOVEMENT). These metonymies were then associated with functional meanings of prominent body-parts and organs, e.g., brain or heart as controlling the rest of the body, face, eyes, arms as oriented to the outside world, hair as non-essential for survival but necessary for beauty. These analogies only resembled the Western ones with regard to a hierarchical bias, e.g. with regard to the head/brains denoting a top position in the body-political hierarchy.

After this first encounter with divergent interpretations, I devised a simple questionnaire-based survey that posed the task to view one's home nation "in terms of a human body". With the generous help of colleagues the survey was administered both in further UEA seminars and in language-/ communication-related courses at other British universities and in Higher Education institutions of nine more countries (China, Croatia, France, Germany, Hungary, Israel, Italy, Lithuania, New Zealand, Norway, Poland, Romania, Saudi-Arabia, Spain, The Netherlands, Ukraine and the USA). The survey has so far yielded more than 1212 questionnaires, which were completed by participants from 31 distinct cultural and linguistic backgrounds (for preliminary analyses cf. Musolff 2016, 2017b). As a rule, it was administered at the start of courses, in order to exclude or minimize any inadvertent 'priming' effects of model answers and aimed at finding out whether any striking distribution patterns emerged that could be related - hypothetically — to specific cultural traditions. $80 \%$ of all informants focused on interpreting the NATION-AS-BODY metaphor in a narrow corporeal meaning as suggested by the stimulus question, whilst one fifth widened it against the prompt to a NATION-AS-PERSON reading. The following sub-sections will present and discuss exemplary cases and main trends for the 171 responses by British and North-American (US/Canadian/New Zealand) students and the 308 ones by their Chinese counterparts.

\subsection{NATION-AS-BODY interpretations}

The bulk of questionnaire responses that followed after the first cohort soon made clear that there is in fact no $1: 1$ match between the variation of institution- or geographybased interpretations of the NATION-AS-BODY metaphor and specific linguistic and/or cultural groups. British and US students' responses, for instance, included geographybased readings such as, "This is Britain, a vast, churning body of 48 million people, sucking in resources, processing them, and spewing out fumes and ideas. The mouth and nose are Dover and Portsmouth <... ". On the other hand, some Chinese students chose to construct institution-based BODY PART analogies that seemed to be typical of the Western body politic tradition, e.g., "The communist party of China is the head of the body. It leads the functions of the whole body system, which decides the entire national affairs". There is thus no absolute contrast between European/Western vs. Chinese-type responses in the sense of specific metaphor version being used exclusively by members of a particular culture but there is a distinct distributional contrast. However, across both cultural cohorts, the main/dominant response version of metaphor construction (institution-based for English L1 speakers; geography-based for Chinese) outnum- 
bered other responses by at least $3: 1$ in both cohorts. Although these ratios cannot be regarded as statistically fully validated, they indicate a clear contrast between the two cohorts, with the first predominantly following the Western body politic tradition, and the latter favouring a construction based on the PLACE-FOR-INSTITUTION metonymy, with a secondary mapping INSTITUTIONAL FUNCTION IS ORGAN/BODY PART-FUNCTION.

When researching relevant cultural traditions to which this territorial/geopolitical motivation could be linked, I found references to a particularly high prominence of China's publicly imagined national "geobody" (Callahan 2009), whose wholeness is part of its national identity. To this day, the Chinese government and media are focused on expressing national claims for "symbolic recognition, acceptance and respect" (2009: 171) in order to overcome the traumatic legacy of Western colonialist aggression during the $19^{\text {th }}$ century and the first half of the $20^{\text {th }}$ century, when China was repeatedly humiliated militarily and diplomatically, forced to give up parts of its territory and even threatened with partition (Bickers 2012; Callahan 2009, 2010; Schneider 2014; Schneider \& Hwang 2014). This Chinese discourse tradition may not be as old as the Western body politic concept but appears to be at least as entrenched in present-day consciousness, which may account for its prominence in our sample. As if to visualise the ideal unified territorial gestalt of the nation's body, one Chinese student even drew up a rough map of China, identifying five key-places: Beijing as the heart, Chengdu and Shanghai as its right and left hands, respectively, and the islands Hainan and Taiwan as its right and left feet that "help China to stand up in the world".

In addition to providing evidence of two dominant tendencies in constructing the NATION-AS-BODY metaphor, the English and Chinese samples also revealed two further versions, which depicted the respective nation either as part/organ of a larger body or as part of one's own personal body. The former perspective can be observed in the following examples: "New Zealand can be seen as then middle toe of the world while one may not acknowledge $<\ldots>$ it when removed, the balance of the body will simply be off"; "China is like a cell, which is a small part of the world" [!]; "China is like vein because it connects with many countries". The alternative "nation-as-part-of $X$ ' version, i.e. NATION AS PART OF ONE'S OWN BODY, shows up in examples such as these: "England is like an appendix, not very significant anymore but can still cause trouble and make you realise its [sic] there if it wants to"; "The US is like the lower back. You really need it and it is a very key part. It also gives a lot of people pain"; "[The Chinese] Motherland likes [sic, presumably intended: is like] my blood. Blood is a part of my body so that I can't live without blood, and I also can't live if I lost my motherland". Compared with ideologically charged interpretations, the two main readings, i.e. the anatomy/function- and geography-based interpretations, are more standardised and repetitive. Overall, the main finding, i.e. evidence of a variation in the construction of metaphor interpretation responses again throws in question the assumption of an 'automatic' production and understanding of metaphors (Lakoff 1993). Instead, our survey shows that responses to metaphor interpretation tasks - when elicited by an open-ended task and with minimal priming - leads to the emergence of distinct sub-versions, of which the two dominant ones (i.e. geography- and institutionbased versions) can be tentatively related to culture-specific discourse traditions. 


\subsection{NATION-AS-PERSON interpretations}

A further main variant, i.e. the mapping NATION AS PERSON accounts for more than one fifth of all responses across both cohorts. The majority of these responses list character traits or activities of PERSON TYPES, as in the following examples: "China welcomes and gives warm hugs to foreigners who come to China. China is growing up day by day. China wears a beautiful dress to show her elegance to the whole world"; "United States is a young girl with a lot of new ideas. She is still excited about trying everything new, so new inventions delight her." Such characterisations of one's nation as a beautiful woman are particularly frequent in the Chinese sample. This Chinese preference for feminine, especially motherly-nurturing nation-PERSONS is perhaps again related to the concern about the integrity of the nation territory, with a literary tradition that depicts regions that were formerly Western colonies as the nation's sons that express their longing to return to their mother, e.g. in the 1925 poem, "Songs of Seven Sons" by the poet Wen Yiduo (1899-1946) (Clayton 2009: 43-44).

The main MASCULINE figure across Chinese and English samples is the old wise $\mathrm{man} /$ (grand-) father/ teacher figure who looks after his family. This type is represented across several national cohorts, as the following examples show: "China is a father who has survived many vicissitudes but still has infinite power. Hong Kong, who had been abandoned helplessly, is his favorite daughter among lots of children"; "Britain is an easily likeable friend $<_{\ldots} . .>[\mathrm{He}]$ is ancient but is experiencing revitalisation $<\ldots$. ". What is absent from both the Chinese and English L1 cohorts is evidence of explicit uses of the STRICT FATHER cognitive model that Lakoff has identified as a powerful ideologicalmoral basis for conservative thought in the USA, in opposition to the NURTURANT PARENT model (1996, 2003, 2004, 2013). Instead, across both the English L1- and Chinese data of our survey, the MALE PERSON figure (FATHER/ BROTHER/ TEACHER) is routinely attributed characterizations that focus on competence, wisdom and helpfulness that fall into the NURTURANT PARENT model, e.g. roles of LAWYER, DOCTOR, PACIFIST, PHILANTHROPIST. This result may well be an effect of age and gender variables in the survey (which consisted of over $70 \%$ responses by female university students aged 18-25); nevertheless, the fact that respondents across both cultural cohorts analysed here produced stance-taking PERSON versions of the NATION-AS-BODY metaphor shows at the very least that elicited metaphor understanding involves a production element that is not predictable from the stimulus/prime of the elicitation task.

Obviously, this 'active understanding' reception of metaphors has to be distinguished from comprehension in a reductionist "processing" sense. Even for the latter aspect of understanding two phases can be distinguished: "an initial phase in which contextually appropriate and salient meanings are activated - the latter automatically and independently of contextual information, the former as a result of a predictive context - and an immediate subsequent phase of integration in which the activated meanings are either retained for further processes or suppressed as conceptually dis-

${ }^{5}$ I am grateful to S.T.D. Wong (Hong Kong) for bringing this link to China's cultural history to my attention. 
ruptive" (Giora 2003, p. 38). For the responses to our elicitation task, a further, interpretation-phase has to be posited that allows for the (re-)construction of conceptually and pragmatically enriched versions, including new metonymy-metaphor combinations, as in the GEOBODY-focused answers.

These findings put the CMT view of metaphor recipients as understanding and automatically accepting the conceptual frame and, together with it, an ideological bias of the metaphors they are presented with further into question. The emergence of distinct trends of metaphor interpretation among specific linguistic and national groups in our survey provides evidence of prominent discourse traditions that may be seen as serving as an interpretation guidance for many respondents. However, this latter result does not imply that the respondents have no choice in their interpretations. Obviously, socially entrenched interpretations provide easily accessible and socio-culturally acceptable models to follow, but they are neither the only ones available nor exempt from reflexive or meta-linguistic uses that enable speakers/writers to put the respective political bias under scrutiny. Unlike the necessity to identify a target referent, which may indeed be mainly a matter of quasi-automatic processing, the decision to accept, endorse and disseminate its bias is in the gift of the receiver.

\section{CONCLUSIONS}

The two sets of data and findings adduced here have in common that they both contain BODY-based metaphors that target political concepts. On the other hand, they are to some degree heterogeneous. One set consisted of 'naturally' occurring media texts, documented in a corpus that had been designed to show the high figurative cohesion in a thematically focused strand of public debate that resulted from the metaphorical slogan, Britain at the heart of Europe, which was quoted, recycled, alluded to and reinterpreted by public voices (media and politicians) in order to emphasise their divergent and changing stances on a specific topic. The second set consisted of elicited responses to an explicit interpretation task that invited respondents to deliberately reconstruct a given conceptual metaphor in application to a variable target referent (the respective home nation). Whilst the task itself was successfully understood and solved, the results showed systematic variation, e.g. in the combination of metonymy and metaphor, which was grouped into five main variants (NATION-AS-GEOBODY, NATIONAS-BODY/BODY PART HIERARCHY, NATION AS PART OF LARGER BODY, NATION AS PART OF SELF'S OWN BODY, NATION AS PERSON). All of these variants were shown to be able to give rise to further pragmatic and argumentative effects, including evaluation and stance-taking.

The two sets of findings complement each other by demonstrating the creative tendencies in both discoursive metaphor production and interpretation responses. Both the production and reception data showed substantial conceptual and pragmatic variation in the use of the two closely related metaphors, HEART AS CENTRE OF LIVING ORGANISM and NATION AS BODY. Some of this variation seems to be linked to culture-specific concept- and discourse-traditions, i.e. as distributional preferences for specific conceptual patterns. Metaphor use appears here as a complex process of metaphor production- 
cum-reception, which goes fundamentally beyond the mere "application" or "processing" of mappings (as envisaged in rigid versions of CMT). Furthermore, instead of assuming immediate access to source concepts and/or frames via figurative discourse stimuli, this perspective posits an intermediate, creative-interpretative level of metaphor production, quotation and reception, which metaphor users can choose to engage with or not, i.e. effectively choosing to 'follow' the standard/dominant/entrenched version of metaphorical conceptualisation or to 'deviate' from it to a smaller or lesser degree so as to achieve extra communicative and cognitive effects.

These findings can only be regarded as explorative, not only because the sampling procedures have not been statistically validated but also insofar as they lack experimental corroboration. Ideally, the authors of the texts in dataset 1 and the survey respondents of dataset 2 should be interviewed and, if possible, externally observed for other variation parameters, in order to capture the cognitive processes in the phases of activation, integration and reinterpretation or modification that characterise communicative uses of metaphor. Providing such evidence to consolidate but also, possibly, correct the conjectures presented here, is a task for future research.

(C) Andreas Musolff, 2019

\section{REFERENCES}

Barnden, J. A. 2009. Metaphor and Context: A Perspective from Artificial Intelligence. In A. Musolff and J. Zinken (Eds.), Metaphor and Discourse (79-94). Basingstoke: Palgrave-Macmillan.

Bickers, R.. 2012. The Scramble for China. Foreign Devils in the Qing Empire. 1832-1914. London: Penguin.

Bowdle, B. F. \& Gentner, D. (2005). The career of metaphor. Psychological Review, 112(1), 193-216.

Brewer's Dictionary of Phrase \& Fable, 1999. Ed. A. Room. London: Cassell.

Callahan, W. A. (2009). The cartography of national humiliation and the emergence of China's geobody. Public Culture 21(1), 141-173.

Callahan, W. A. (2010). China - The Pessoptimist Nation. Oxford: Oxford University Press.

Charbonnel, N. (2010). Comme un seul home. Corps politique et corps mystique. 2 vols. Lons Le Saunier: Aréopage.

Clayton, C. H. (2009). Sovereignty at the Edge: Macau \& the Question of Chineseness. Cambridge, MA: Harvard University Press.

Chilton, P., \& Lakoff, G. (1995). Foreign Policy by Metaphor. In C. Schäffner \& A. Wenden (Eds.). Language and Peace (pp. 37-55). Aldershot: Ashgate.

Connolly, B. (1995). The Rotten Heart of Europe. London: Faber.

Croft, W. and Cruse, D.A. (2004). Cognitive Linguistics. Cambridge: Cambridge University Press.

Culpeper, J. (2011). Impoliteness: Using Language to Cause Offence. Cambridge: Cambridge University Press.

de Baecque, A. (1997). The Body Politic. Corporeal Metaphor in Revolutionary France 1770-1800. Stanford, CA: Stanford University Press.

Fauconnier, G. \& Turner, M. (2002). The Way we Think: Conceptual Blending and the Mind's Hidden Complexities. New York: Basic Books.

Giora, R. (2003). On our Mind: Salience, context, and figurative language. New York: Oxford University Press. 
Goatly, A. (1997). The Language of Metaphors. London: Routledge.

Guldin, R. (2000). Körpermetaphern: Zum Verhältnis von Politik und Medizin. Würzburg: Königshausen \& Neumann.

Hansard (1991). House of Commons Debate on the European Council in Maastricht 11 December 1991 (Hansard vol. 200, cc. 859-78). http://hansard.millbanksystems.com/commons/1991/dec/ 11/european-council-maastricht (accessed 22 September 2017).

Idström, A. \& Piirainen, E. (Eds.) (2012). Endangered Metaphors. In cooperation with Falzett, T.F.M. Amsterdam: John Benjamins.

Kantorowicz, E. H. (1997). The King's Two Bodies: A Study in Mediaeval Political Theology. With a new Preface by W. C. Jordan. Princeton, NJ: Princeton University Press.

Kövecses, Z. (2002). Metaphor. A Practical Introduction. Oxford/New York: Oxford University Press.

Kövecses, Z. (2005). Metaphor in Culture: Universality and Variation. Cambridge: Cambridge University Press.

Kövecses, Z. (2006). Language, Mind and Culture. A Practical Introduction. Oxford / New York: Oxford University Press.

Kövecses, Z. (2009). Metaphor, Culture, and Discourse: The Pressures of Coherence. In: A. Musolff \& J. Zinken (Eds.). Metaphor and Discourse (pp. 11-24). Basingstoke: Palgrave-Macmillan.

Lakoff, G. (1987). The Death of Dead Metaphor. Metaphor \& Symbolic Activity, 2(2), 143-147.

Lakoff, G. (1993). The contemporary theory of metaphor. In A. Ortony (Ed.). Metaphor and Thought (pp. 202-251). Cambridge: Cambridge University Press.

Lakoff, G. (1996). Moral Politics: What Conservatives Know That Liberals Don't. Chicago: University of Chicago Press.

Lakoff, G. (2003). Metaphor and War, Again. http://www.alternet.org/story.html?StoryID=15414 (accessed 21/09/2017).

Lakoff, G. (2004). Don't Think of an Elephant! Know Your Values and Frame the Debate. The essential guide for progressives. White River Junction, VT: Chelsea Green Publishing Company.

Lakoff, G. (2008). The neural theory of metaphor. In: R. W. Gibbs (ed.). The Cambridge Handbook of Metaphor and Thought (pp. 17-38) Cambridge: Cambridge University Press.

Lakoff, G. (2013). Obama Reframes Syria: Metaphor and War Revisited. The Huffington Post, 6 September 2013. http://georgelakoff.com/2013/09/06/obama-reframes-syria-metaphor-and-warrevisited/ (accessed 21/09/2017).

Lakoff, G. \& M. Johnson (1980/2003). Metaphors we live by. Chicago: University of Chicago Press.

Lakoff, G. \& M. Johnson (1999). Philosophy in the Flesh. New York: Basic Books.

Lakoff, G. \& Turner, M. (1989). More than Cool Reason. A Field Guide to Poetic Metaphor. Chicago: University of Chicago Press.

Littlemore, J. (2001). The use of Metaphor in University Lectures and the problems that it causes for overseas students. Teaching in Higher Education 6, 331-349.

Littlemore, J. (2003). The Effect of Cultural Background on Metaphor Interpretation. Metaphor and Symbol, 18(4), 273-288.

Littlemore, J., Chen, P. Koester, A. \& Barnden, J. (2011). Difficulties in metaphor comprehension faced by international students whose first language is not English. Applied Linguistics, 32(4), $408-429$.

Lovejoy, A. O. (1936). The Great Chain of Being. Cambridge, MA: Harvard University Press.

Major, J. (2000). The Autobiography. London: HarperCollins.

Müller, C. (2008). Metaphors Dead and Alive, Sleeping and Waking: A Dynamic View. Chicago, IL: University of Chicago Press. 
Musolff, A. (2004a). Metaphor and Political Discourse. Analogical Reasoning in Debates about Europe. Basingstoke: Palgrave-Macmillan.

Musolff, A. (2004b). The Heart of the European Body Politic. British and German Perspectives on Europe's Central Organ. Journal of Multilingual \& Multicultural Development, 25 (5 \& 6), $437-452$.

Musolff, A. (2006). Metaphor Scenarios in Public Discourse. Metaphor and Symbol, 21(1), 23-38.

Musolff, A. (2010). Metaphor, Nation and the Holocaust. The Concept of the Body Politic. London: Routledge.

Musolff, A. (2013). The heart of Europe: Synchronic variation and historical trajectories of a Political Metaphor. In Fløttum, K. (Ed.), Speaking of Europe: Approaches to complexity in European political discourse (pp. 135-150). Amsterdam: John Benjamins.

Musolff, A. (2016). Cross-Cultural Variation in Deliberate Metaphor Interpretation. Metaphor and the Social World 6(2): 205-224.

Musolff, A. (2017a). Metaphor, irony and sarcasm in public discourse. Journal of Pragmatics, $109,95-104$.

Musolff, A. (2017b). Metaphor and Cultural Cognition'. In Sharifian, F. (ed.). Advances in Cultural Linguistics (pp. 325-344). Singapore: Springer.

Musolff, A., MacArthur, F. \& Pagani, G. (Eds.). (2014). Metaphor and Intercultural Communication. London: Bloomsbury.

Nacey, S. (2013). Metaphors in Learner English. Amsterdam: John Benjamins.

Piquer-Píriz, A. (2010). Can people be cold and warm? Developing understanding of figurative meanings of temperature terms in early EFL. In G. Low, Z. Todd, A. Deignan, \& L. Cameron (Eds.), Researching and Applying Metaphor in the Real World (pp. 21-34). Amsterdam: John Benjamins.

Philip, G. (2010). "Drugs, traffic, and many other dirty interests": Metaphor and the language learner. In G. Low, Z. Todd, A. Deignan and L. Cameron (Eds.), Researching and Applying Metaphor in the Real World (pp. 63-80). Amsterdam: John Benjamins.

Roget's International Thesaurus, 1996. Ed. Chapman, R. Glasgow: HarperCollins.

Shorter Oxford English Dictionary (2002). Eds. Trumble, W. R. \& Stevenson, A. Oxford: Oxford University Press.

Schneider, F. (2014). It's a small world after all? Simulating the future world order at the Shanghai Expo. In Q. Cao, H. Tian \& P. Chilton (eds.), Discourse, Politics and Media in Contemporary China (pp. 97-120). Amsterdam: John Benjamins.

Schneider, F. \& Hwang, Y-J. (2014). China's Road to Revival. "Writing" the PRC's struggles for modernization. In Q. Cao, H. Tian \& P. Chilton (eds.), Discourse, Politics and Media in Contemporary China (pp. 145-170). Amsterdam: John Benjamins.

Sontag, S. (1978). Illness as Metaphor. New York: Vintage Books.

Sperber, D. (Ed.) (2000). Metaprepresentations: a multidisciplinary perspective. Oxford: Oxford University Press.

Sperber, D. \& Wilson, D. (1995). Relevance. Communication and Cognition. Oxford: Blackwell.

Steen, G. (2008). The paradox of metaphor: Why we need a three-dimensional model of metaphor. Metaphor and Symbol 23 (4), 213-241.

Steen, G. (2011). What does 'really deliberate' really mean? More thoughts on metaphor and consciousness and action. Metaphor and the Social World 1 (1), 53-56.

Tendahl, M. \& Gibbs, R. W. (2008). Complementary perspectives on metaphor: Cognitive linguistic and relevance theory. Journal of Pragmatics 40(1), 1823-1864. 
Trim, R. (2011). Metaphor and the Historical Evolution of Conceptual Mapping. Basingstoke: Palgrave Macmillan.

Trim R. (2012). The limits of Comprehension in Cross-Cultural Metaphor: Networking in Drugs Terminology. In F. MacArthur, J. L. Oncins-Martínez, M. Sánchez-García, \& A. M. PiquerPíriz (Eds.), Metaphor in Use: Context, culture, and communication (pp. 217-238). Amsterdam: John Benjamins.

Weinreich, H. (1983). Die Semantik der kühnen Metapher. In A. Haverkamp (Ed.). Theorie der Metapher (pp. 316-339). Darmstadt: Wissenschaftliche Buchgesellschaft.

Wilson, D. \& Sperber, D. (1992). On verbal irony. Lingua 87, 53-76.

Wilson, D. \& Sperber, D. (2012). Explaining irony. In D. Wilson \& D. Sperber (Eds.). Meaning and Relevance (pp. 123-145). Cambridge: Cambridge University Press.

\author{
Article history: \\ Received: 21 October 2018 \\ Revised: 10 December 2018 \\ Accepted: 29 December 2018
}

\title{
История статьи:
}

Дата поступления в редакцию: 21 октября 2018

Дата принятия к печати: 29 декабря 2018

\section{For citation:}

Musolff, Andreas (2019). Creativity in Metaphor Interpretation. Russian Journal of Linguistics, 23 (1), 23-39. doi: 10.22363/2312-9182-2019-23-1-23-39.

\section{Для цитирования:}

Musolff, Andreas. Creativity in Metaphor Interpretation // Вестник Российского университета дружбы народов. Серия: Лингвистика = Russian Journal of Linguistics. 2019. T. 23. No 1. С. 2339. doi: 10.22363/2312-9182-2019-23-1-23-39.

\section{Bionote:}

ANDREAS MUSOLFF is Professor of Intercultural Communication at the University of East Anglia in Norwich (UK). His research interests focus on Cultural Metaphor Studies, Intercultural and Multicultural communication, and Public Discourse Analysis. He has published widely on figurative language use in the public sphere, e.g. the monographs Political Metaphor Analysis - Discourse and Scenarios (2016), Metaphor, Nation and the Holocaust (2010), Metaphor and Political Discourse (2004), and the co-edited volumes Metaphor and Intercultural Communication (2014), Contesting Europe's Eastern Rim: Cultural Identities in Public Discourse (2010) and Metaphor and Discourse (2009).

Contact information: e-mail: A.Musolff@uea.ac.uk

\section{Сведения об авторе:}

АНДРЕАС МУЗОЛФ — профессор, преподает межкультурную коммуникацию в Университете Восточной Англии в Норвиче (Великобритания). Сфера научных интересов - исследование метафоры в культурологическом аспекте; межкультурная и мультикультурная коммуникация; публичный дискурс. Имеет многочисленные публикации, посвященные использованию языковой образности в публичном дискурсе, в т.ч. монографии «Анализ политической метафоры дискурс и сценарии» (2016), «Метафора, нация и холокост» (2010), «Метафора и политический дискурс» (2004); выступал в качестве соредактора коллективных монографий «Метафора и межкультурная коммуникация» (2014), «Где находится восточная граница Европы: культурные идентичности в публичном дискурсе» (2010), «Метафора и дискурс» (2009).

Контактная информация: e-mail: A.Musolff@uea.ac.uk 